\title{
Black-tailed Prairie Dog Food Habits and Forage Relationships in Western South Dakota
}

\author{
DANIEL W. URESK
}

\begin{abstract}
Four plants made up $65 \%$ of items in fecal pellets of the blacktalled prairie dog in western South Dakota. These important forages in order of significance were sand dropseed, sun sedge, blue grama, and wheatgrasses. Grasses made up $87 \%$ of the total diet, while forbs comprised $12 \%$. Shrubs, arthropods, and seeds made up $1 \%$ or less of the diet. Preference indices were highest for ring muhly, green needlegrass, and sand dropseed. Relationships of diets to available forage was weak, having an average similarity of 25\%; rank-order correlations were nonsignificant, indicating that black-tailed prairie dogs are selective feeders.
\end{abstract}

Black-tailed prairie dogs (Cynomys ludovicianus) are common herbivores on western rangelands. Much attention, since the 1800 's, has focused on forage competition between livestock and prairie dogs. Widespread control programs for prairie dogs were begun in the late 1800 's and early 1900 's on the Great Plains, when it was estimated that 256 prairie dogs would eat as much forage as 1 cow (Merriam 1902). The concern over livestock and prairie dog grazing competition still exists; large-scale control programs for prairie dogs are being conducted even with costs as high as $\$ 6 / a c r e$ on land which generates grazing fees of $\$ 2.95 /$ acre (Collins et al. 1984).

Dietary information is essential to assess the role of the prairie dog in prairie ecosystems. Since Kelso (1939) first presented general data on black-tailed prairie dog diets, research has been conducted in Colorado (Tileston and Lechleitner 1966, Bonham and Lerwick 1976, Hansen and Gold 1977); Montana (Fagerstone et al. 1977); and South Dakota (Summers and Linder 1978, Fagerstone et al. 1981). Dietary information is presented in these studies; however, data on diet-forage relationships and preference indices are generally lacking. Most of these studies were conducted in National Parks or in areas with limited grazing by cattle. Dietary information by species will vary from region to region even though major categories consumed by prairie dogs (grasses, forbs, shrubs) are similar. Intensive management of our rangelands must be based on plant species consumed by herbivores in the area of interest.

The purpose of this study was to estimate the diets of blacktailed prairie dogs as related to the availability of range vegetation on pastures grazed by cattle, and to determine preference indices for commonly consumed plants in western South Dakota.

\section{Study Area and Methods}

The study was conducted in Conata Basin, approximately $29 \mathrm{~km}$ south of Wall, S. Dak. Topography of the area is gently undulating shortgrass prairie. Annual precipitation at the Cottonwood Climatological Station, approximately $30 \mathrm{~km}$ east of the study area, was $38 \mathrm{~cm}$, of which $79 \%$ fell from April through September. Average annual temperature was $8^{\circ} \mathrm{C}$.

\footnotetext{
Author is research biologist with Rocky Mountain Forest and Range Experimen Station, Rapid City, S. Dak., in cooperation with the South Dakota School of Mines and Technology. The station's headquarters is in Fort Collins, in cooperation with Colorado State University.

Manuscript accepted November 3, 1983.
}

Major grass and grasslike plants of the study area included blue grama (Bouteloua gracilis), buffalograss (Buchloe dactyloides), needleleaf sedge (Carex eleocharis), and red threeawn (Aristida longiseta). Forbs included scarlet globemallow (Sphaeralcea coccinea), Patagonia indianwheat (Plantago patagonica), and prairie dog dogweed (Dyssodia papposa). Shrubs included snakeweed (Xanthocephalum sarothrae) and silver sagebrush (Artemisia cana).

The rangeland was grazed by both cattle and black-tailed prairie dogs. Cattle grazed the area from approximately mid-May to the last of October. Stocking levels were high but varied from year to year depending upon moisture and available forage. Forage utilization during the grazing season was generally greater than $60 \%$.

Fecal pellets of black-tailed prairie dogs were collected from 3 prairie dog towns, representing approximately 1,700 ha. On each dog town, an area $50 \mathrm{~m} \times 50 \mathrm{~m}(0.25 \mathrm{ha})$ was permanently located. All pellets were initially cleared from all replicated sites. A minimum of 300-400 fecal pellets were collected on a monthly basis from March to September on each site. All pellets by site were dried at $60^{\circ} \mathrm{C}$ for 48 hours and ground through a Wiley mill $(1-\mathrm{mm}$ screen) to insure thorough mixing.

Five microscope slides were prepared monthly from the composited fecal pellets from each site. All fecal material was washed over a 0.1-mm screen (Sparks and Malechek 1968). Fecal material was cleared of chlorophyll and other compounds with Hertwig's solution. Hoyer's solution was used as a mounting medium (Baumgartner and Martin 1939), and the slides were dried for approximately 72 hours at $60^{\circ} \mathrm{C}$.

Twenty microscope fields per slide were systematically located ( 500 fields/site), magnified 100 times, and all recognizable plant fragments were recorded. Frequency of occurrence was determined by dividing the number of microscopic fields in which a given species occurred by the total number of fields observed $\times 100$ (Curtis and McIntosh 1959). Test slides were prepared for samples of known plant species to measure the ability to properly and consistently identify plant fragments. Testing was applied according to the procedures outlined by Rogers and Uresk (1974).

Vegetation at each sample site was measured for canopy cover and frequency of occurrence by species. In each of the 3 replicated sites, 3 parallel line transects, $50 \mathrm{~m}$ long and $25 \mathrm{~m}$ apart, were established. Canopy cover and frequency of occurrence was estimated by methods outlined by Daubenmire (1959). Estimations were determined by ocular examination of $50\left(2 \times 5 \mathrm{dm}, 0.1 \mathrm{~m}^{2}\right)$ quadrats systematically spaced at $1-\mathrm{m}$ intervals along each $50-\mathrm{m}$ line transect. Canopy cover and frequency of occurrence values were summarized by line transects.

Kulczynski's similarity index (Oosting 1956) and Spearman's rank order correlation $\left(r_{4}\right)$ (Siegel 1956) were calculated for prairie dog diets and forage abundance to determine degree of association. Preference indices were calculated by dividing relative frequency of plants in the diet by the relative frequency of available plants (Krueger 1972). When a plant species was present in the diet but not sampled on the rangeland, a $0.1 \%$ frequency value was used. 
Table 1. Average frequency of occurrence $(\% F)$ and canopy cover $(\% C)$ of plants during the summer months in Conata Basin, South Dakota.

\begin{tabular}{|c|c|c|c|c|c|c|c|c|}
\hline \multirow[b]{2}{*}{ Category } & \multicolumn{2}{|c|}{ May } & \multicolumn{2}{|c|}{ July } & \multicolumn{2}{|c|}{ August } & \multicolumn{2}{|c|}{ September } \\
\hline & $\mathbf{F}$ & C & F & c & $\mathbf{F}$ & c & $\mathbf{F}$ & C \\
\hline \multicolumn{9}{|l|}{ Grass and Grasslikes } \\
\hline Wheatgrass (Agropyron spp.) & 8.7 & .7 & 12.2 & 0.7 & 8.0 & 0.5 & 6.6 & 0.5 \\
\hline Red threea wn (Aristida longiseta) & 28.2 & 4.7 & 21.8 & 5.0 & 25.1 & 10.6 & 25.1 & 8.1 \\
\hline Blue grama (Bouteloua gracilis) & 52.9 & 15.6 & 67.6 & 27.6 & 69.8 & 32.9 & 64.2 & 22.5 \\
\hline Japanese brome (Bromus japonicus) & & & 0.4 & $<0.1$ & 1.1 & $<0.1$ & & \\
\hline Buffalograss (Buchloe dactyloides) & 74.0 & 30.7 & 73.3 & 33.6 & 74.4 & 36.4 & 78.9 & 42.0 \\
\hline $\begin{array}{l}\text { Needleleaf sedge (Carex eleocharis) } \\
\text { Sixweeks fescue (Festuca octoflora) }\end{array}$ & 79.1 & 8.4 & $\begin{array}{r}76.2 \\
7.1\end{array}$ & $\begin{array}{r}11.3 \\
0.2\end{array}$ & $\mathbf{7 4 . 0}$ & 12.5 & 71.3 & 6.3 \\
\hline $\begin{array}{l}\text { Tumble grass (Schedonnardus } \\
\text { paniculatus) }\end{array}$ & 33.6 & 5.8 & 36.9 & 11.8 & 29.8 & 9.3 & 37.6 & 7.7 \\
\hline Sand dropseed (Sporobolus & & & & & & & & \\
\hline $\begin{array}{l}\text { cryptandrus) } \\
\text { False buffalograss (Munroa }\end{array}$ & 2.2 & 0.3 & 3.6 & 0.3 & 12.6 & 3.9 & 0.9 & $<0.1$ \\
\hline squarrosa) & & & 0.2 & $\leq 0.1$ & 1.3 & $\leq 0.1$ & 4.7 & 0.1 \\
\hline Total & & 66.2 & & 90.6 & & 106.2 & & 87.2 \\
\hline \multicolumn{9}{|l|}{ Forbs } \\
\hline Milkvetch (Astragalus spp.) & 5.1 & $<0.1$ & 10.4 & .3 & 12.7 & 0.5 & 9.3 & 0.4 \\
\hline $\begin{array}{l}\text { Scarlet gaura (Gaura coccinea) } \\
\text { Sage (Salvia reflexa) }\end{array}$ & 0.2 & $<0.1$ & 0.7 & $<0.1$ & $\begin{array}{l}0.7 \\
0.2\end{array}$ & $\begin{array}{l}<0.1 \\
<0.1\end{array}$ & 0.4 & $<0.1$ \\
\hline $\begin{array}{l}\text { Pussytoes (Antemnaria dimorpha) } \\
\text { Yellow sweetclover (Melilotus }\end{array}$ & 3.1 & 0.1 & & & 0.2 & $<0.1$ & 0.2 & $<0.1$ \\
\hline $\begin{array}{l}\text { officinalis) } \\
\text { Skelton plant (Lygodesmia juncea) }\end{array}$ & 2.2 & $<.1$ & 0.4 & $<0.1$ & $\begin{array}{l}0.8 \\
0.4\end{array}$ & $\begin{array}{r}0.1 \\
<0.1\end{array}$ & 2.4 & 0.1 \\
\hline $\begin{array}{l}\text { Prostrate knotweed (Polygonum } \\
\text { aviculare) }\end{array}$ & 6.2 & 0.2 & 0.9 & $<0.1$ & 0.2 & $<01$ & 0.4 & $<01$ \\
\hline Patagonia Indianwheat (Plantago & 0.2 & & 0.9 & $<0.1$ & 0.2 & $<0.1$ & 0.4 & $<0.1$ \\
\hline $\begin{array}{l}\text { patagonica) } \\
\text { Scarlet globemallow (Sphaeralcea }\end{array}$ & 7.8 & 0.4 & 7.6 & 0.3 & 4.9 & 0.5 & 3.3 & 0.1 \\
\hline coccinea) & 79.4 & 7.1 & 79.6 & 6.0 & 74.0 & 5.9 & 73.6 & 4.2 \\
\hline $\begin{array}{l}\text { Carolina draba (Draba reptans) } \\
\text { Ridgeseed euphorbia (Euphorbia }\end{array}$ & 2.9 & 0.2 & 0.7 & $<.1$ & & & & \\
\hline glytosperma) & & & 11.1 & 0.5 & 12.2 & 0.7 & 16.7 & 1.0 \\
\hline $\begin{array}{l}\text { Drummond falsepennyroyal } \\
\text { (Hedeoma drummondii) }\end{array}$ & 0.2 & $<01$ & 93 & 03 & 38 & $<0.1$ & 13 & $<01$ \\
\hline Common starlily (Leucocrinum & 0.2 & -0.1 & 8.0 & 0.0 & (N.0 & -0.4 & 1.0 & 0.1 \\
\hline montanum) & 1.6 & 0.1 & & & & & & \\
\hline Musineon (Musineon divaricatum) & 9.6 & 0.4 & & & & & & \\
\hline $\begin{array}{l}\text { Pale eveningprimrose (Oenothera } \\
\text { pallida) }\end{array}$ & 0.4 & $<0.1$ & & & & & & \\
\hline \multicolumn{9}{|l|}{ Bigbract verbena (Verbena } \\
\hline bracteata) & 4.2 & 0.1 & 8.9 & 0.4 & 8.7 & 0.9 & 8.7 & 0.5 \\
\hline $\begin{array}{l}\text { American vetch (Vicia americana) } \\
\text { Plains pricklypear (Opuntia }\end{array}$ & 7.3 & 0.4 & 1.8 & $<0.1$ & 0.9 & 0.1 & 1.1 & $<0.1$ \\
\hline polyacantha) & 4.4 & 1.3 & 3.1 & 0.8 & 4.0 & 1.4 & 3.6 & 0.5 \\
\hline $\begin{array}{l}\text { Meadow deathcamas (Zigadenus } \\
\text { venenosus) } \\
\text { Prairie dogweed (Dyssodia }\end{array}$ & 7.6 & 1.2 & & & & & & \\
\hline $\begin{array}{l}\text { papposa) } \\
\text { Snow-on-the mountain (Euphorhia }\end{array}$ & & & 30.0 & 3.8 & 29.6 & 4.2 & 34.4 & 5.0 \\
\hline $\begin{array}{l}\text { Snow-on-the mountain (Euphorhia } \\
\text { marginata) }\end{array}$ & 0.9 & $<0.1$ & 1.1 & $<.1$ & 1.1 & 0.2 & 0.4 & 1.2 \\
\hline Stickseed (Lappula redowskii) & & & 1.3 & $<0.1$ & 0.2 & $<0.1$ & 0.2 & $<0.1$ \\
\hline Stiffstem flax (Linum rigidum) & & & 0.9 & $<0.1$ & 0.2 & $<0.1$ & & \\
\hline \multicolumn{9}{|l|}{ Mammillaria (Mammillaria } \\
\hline $\begin{array}{l}\text { vivipara) } \\
\text { Euphothia (Euphorbia Sp) }\end{array}$ & & & 0.2 & $<0.1$ & & & & \\
\hline \multicolumn{9}{|l|}{ Cutleaf nightshade (Solanum } \\
\hline triflorum) & & & 0.4 & 0.1 & 0.4 & 0.1 & 1.6 & 0.1 \\
\hline \multicolumn{9}{|l|}{ Meadow salsify (Tragopogon } \\
\hline $\begin{array}{l}\text { pratensis) } \\
\text { Unknowns }\end{array}$ & & & 0.2 & $<0.1$ & & & $\begin{array}{l}0.4 \\
0.2\end{array}$ & $\begin{array}{l}<0.1 \\
<0.1\end{array}$ \\
\hline Total & & 11.8 & & 13.2 & & 15.9 & & 14.0 \\
\hline \multicolumn{9}{|l|}{ Shrubs } \\
\hline \multicolumn{2}{|l|}{$\begin{array}{l}\text { Snakeweed (Xanthocephalum sarothrae) } \\
\text { Total cover }{ }^{1}\end{array}$} & 73.3 & 0.2 & $\begin{array}{l}<0.1 \\
86.8\end{array}$ & 0.2 & $\begin{array}{l}<0.1 \\
91.4\end{array}$ & & 86.0 \\
\hline
\end{tabular}

ITwo dimensional cover 
Table 2. Average botanical composition $(\%)$ of fecal pellets collected from black-tailed prairie doge in Conata Banin, South Dakota.

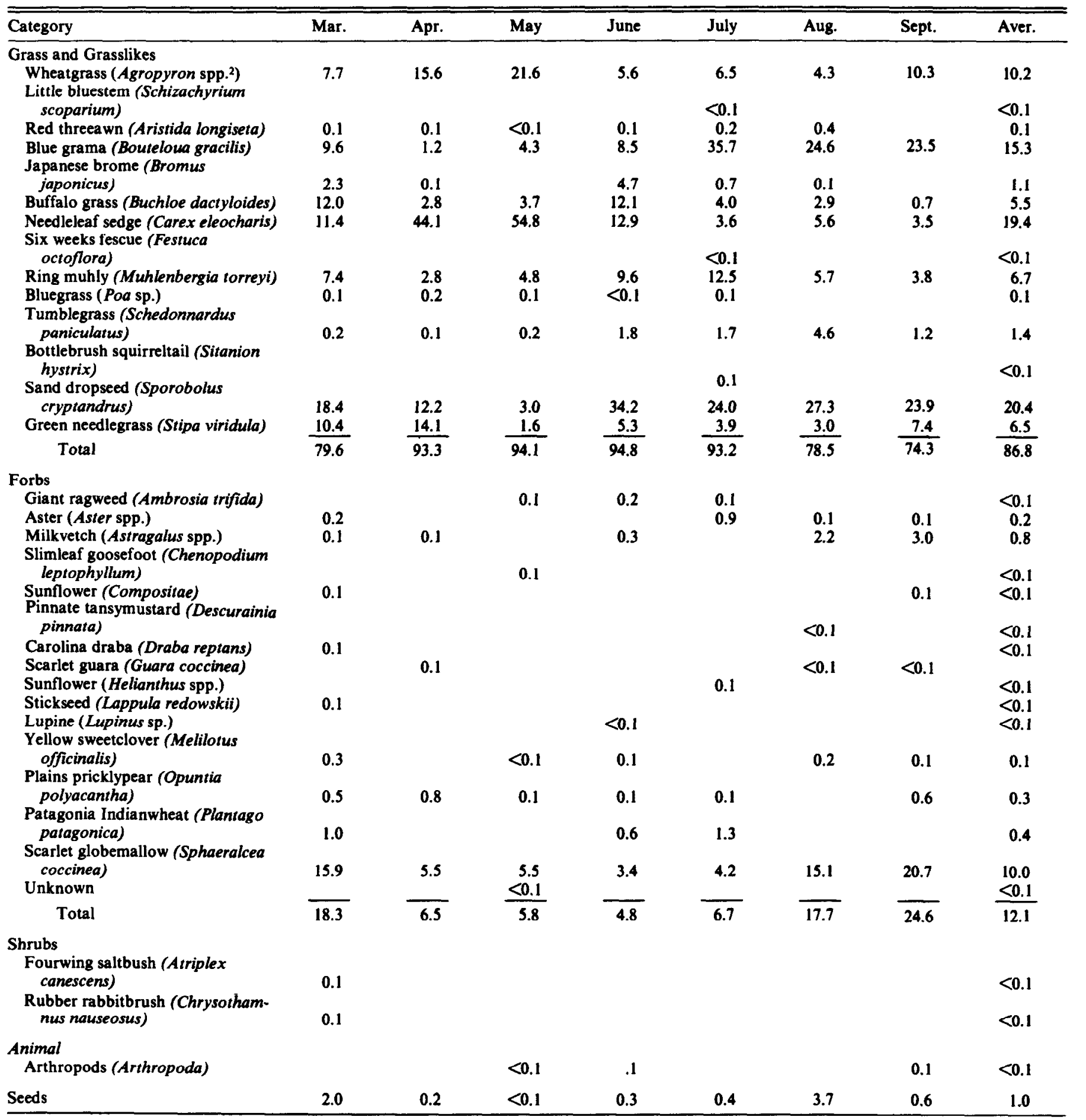

'Calculated by relative density values

${ }^{2}$ A. smithii and A. desertorum 


\section{Results}

\section{Vegetation}

A total of 39 plant species was identified on the study area (Table 1). Frequency of occurrence was highest throughout the summer months for buffalograss, sun sedge, blue grama, and scarlet globemallow. Forbs, primarily annuals, showed the lowest frequency of occurrence.

Grasses and sedges provided most of the canopy cover (Table 1), ranging from $66 \%$ to $106 \%$ throughout the summer season, and consisting mainly of buffalograss and blue grama. Forbs provided less canopy cover, ranging from $13 \%$ to $16 \%$. Scarlet globemallow and prairie dogweed comprised most of the forb cover. Shrub cover was insignificant. Total two-dimensional, canopy cover during the summer ranged from $73 \%$ to $91 \%$.

\section{Diets}

Thirty one plant species were identified in black-tailed prairie dog fecal pellets (Table 2). Fourteen grass species, 15 forbs, 2 shrubs, and arthropods made up the diet. Sand dropseed (Sporobolus cryptandrus) was the most abundant plant found in the pellets, ranging from $3 \%$ to $34 \%$. Other grasses and grasslike plants included needleleaf sedge, blue grama, and wheatgrasses (Agropyron spp.). Grasses and grasslike plants provided $87 \%$ of the total diet, varying from $74 \%$ to $95 \%$ from March through September. Forbs were less important, providing approximately $12 \%$ of the total diet. The major forb found in prairie dog fecal samples was scarlet globemallow. It varied throughout the 7 months of study from $3 \%$ in June to a high of $21 \%$ in September. Forbs were lowest in the prairie dog diet during June (5\%) and highest in September (25\%). Shrubs were a minor component in the prairie dog diet, as were arthropods and seeds.

Grasses and grasslike plants were the most preferred forage plants during the 4-month period when vegetation was sampled (Table 3). Ring muhly (Muhlenbergia torreyi) was the most highly preferred species. Other highly preferred forage plants in decreasing order included green needlegrass (Stipa virdula) and sand dropseed. The average preference index ranged from 17 in September to 8 in May.

Average percent similarities and rank order correlations were low when comparing diets with forage. Prairie dog diets and forage were $25 \%$ similar for each of the 4 summer months. Rank order correlation coefficients for diets compared to forage were not significant--0.13,0.25, 0.25, and 013 for May, July, August and September, respectively. Further, Spearman's correlation of preference indices with rangeland plants were nonsignificant. Correlation coefficients were $-0.21,-0.08,-0.02,-0.15$ for each of the 4 months.

Similarity indices of diets when compared among all 7 months were low, ranging from $24 \%$ to $53 \%$, indicating that forage plants were not consumed in similar amounts over all months. Spearman's correlations among monthly diets were all significant $(P \leq .01$ ), ranging from 0.56 to 0.86 . The forage plants were consumed by prairie dogs in somewhat the same relative rankings throughout all 7 months of study.

\section{Discussion}

Sand dropseed and sun sedge were important forage species for the black-tailed prairie dog in addition to what was reported by Summers and Linder (1978) and Fagerstone et al. (1981). Consumption of the 2 forages may be related to nutritional qualities and requirements of the prairie dog. Sun sedge has a higher crude protein content than most other grass species (Uresk, unpublished data), but information for sand dropseed is lacking. Summers and Linder (1978), in South Dakota, reported that important forage plants for black-tailed prairie dog were buffalograss, scarlet globemallow, threadleaf sedge ( $C$. filifolia), blue grama, and western wheatgrass (A. smithii). In addition, Fagerstone et al. (1981) showed that cactus (Opuntia sp.) was an important forage plant for prairie dogs.
Table 3. Relative prairie dog preference indices of forage plants during the summer months.

\begin{tabular}{|c|c|c|c|c|}
\hline Category & May & July & August & September \\
\hline \multicolumn{5}{|l|}{ Grasses and Grasslikes } \\
\hline Wheatgrass & 10.8 & 3.0 & 3.2 & 6.1 \\
\hline Little bluestem & & .9 & & \\
\hline Red threeawn & $<.1$ & .1 & .1 & \\
\hline Blue grama & .6 & 2.1 & 1.4 & 1.2 \\
\hline Japanese brome & & 1.2 & .6 & \\
\hline Buffalograss & .3 & .3 & .2 & .4 \\
\hline Needleleaf sedge & 2.1 & .3 & .4 & .2 \\
\hline Sixweeks fescue & & .1 & & \\
\hline Ring muhly & 78.1 & 137.7 & 68.7 & 47.5 \\
\hline Bluegrass & 2.3 & .9 & & \\
\hline Tumble grass & $<.1$ & .3 & .9 & .2 \\
\hline Bottlebrush squirreltail & & .9 & & \\
\hline Sand dropseed & 9.6 & 46.1 & 9.0 & 113.7 \\
\hline Green needlegrass & 27.0 & 47.9 & 36.7 & 89.4 \\
\hline \multicolumn{5}{|l|}{ Forbs } \\
\hline Aster & & & 1.2 & 1.1 \\
\hline Milkvetch & .5 & & 1.0 & 1.6 \\
\hline Slimleaf goosefoot & .9 & & & \\
\hline Pinnate tansymustard & & & .8 & \\
\hline Scarlet gaura & & & .4 & \\
\hline Sunflower & & & & 1.1 \\
\hline Yellow sweetclover & .2 & & 2.9 & .2 \\
\hline Giant ragweed & 1.4 & 1.4 & & \\
\hline Patagonia Indianwheat & & 1.0 & & \\
\hline Scarlet globemallow & .5 & .4 & 1.0 & 1.1 \\
\hline Unknown & .9 & & & \\
\hline \multicolumn{5}{|l|}{ Shrubs } \\
\hline Plains pricklypear & .2 & .2 & & .7 \\
\hline \multicolumn{5}{|l|}{ Other } \\
\hline Seeds & & 5.6 & 43.7 & 8.4 \\
\hline Arthropods & .9 & & & 1.1 \\
\hline Average & 7.6 & $\overline{13.2}$ & 10.1 & 17.1 \\
\hline
\end{tabular}

The highest preference indices occurred for forage plants that were not abundant on the rangeland. These plants included ring muhly, green needlegrass and sand dropseed, which are all uncommon perennial grasses on the range. This highly selective feeding habit of the prairie dog can be influential in keeping these perennial grasses from increasing in abundance. Ring muhly and sand dropseed are not considered good forage species for cattle, while green needlegrass is excellent forage. Buffalograss and bluegrama (which are considered good cattle forage species) were abundant on the rangeland, but preference indices were low for these plants, indicating that prairie dogs were not seeking out these forages. Forbs were not preferred food items for the black-tailed prairie dog, although most of the forb species were very common on the rangeland, which can explain the abundance of forbs on prairie dog towns (Bonham and Lerwick 1976; and Uresk and Bjugstad 1983). However, prairie dogs have been shown to be highly adaptable feeders. When the forage resource is stressed by grazing, drought, or herbicides, they change their diets within a relatively short time. Fagerstone et al. (1977) reported that prairie dog diets changed significantly from forbs to grasses after forb coverage was reduced by spraying with 2,4-D.

Average percent similarities and rank order correlations were low when diets were compared to available forage, indicating that prairie dogs are not consuming plants in the same relative order as they occur on the range, and thus are selecting for certain plants. When preference indices were compared to forage availability, low correlation coefficients indicated that prairie dog diets showed little relationship to forage availability on the range. Generally, preferences were inversely related to availability.

Seasonal trends in diets for grasses and forbs varied, which was 
due to a dietary shift, and not dietary analysis error. Wydeven and Dahlgren (1982) compared stomach contents to fecal samples from black-tailed prairie dogs during 3 periods in the summer, and concluded that fecal material provided as reliable an estimate of grasses and forbs as stomach contents. Digestibility was not a factor in plant identification or loss of forbs. Johnson et al. (1983) found that digestion does not significantly alter botanical compositions. Discernibility of some plants is affected by digestion, but the impact on the estimated botanical composition will rarely cause significant alterations in diet estimates. Uresk and Rickard (1976a,b), working with cattle, found that diet data obtained by microscopic examination of plant species in fecal samples correlated very well with plants harvested by clipping and utilization measurements obtained in the field under moderate spring grazing. In our study, true preference indices may be higher for the forbs than shown in Table 3 (if one assumes there has been a slight loss through digestion), and lower for the grasses. Some limitations and positive aspects of microscopic techniques are presented by Holechek et al. (1982), Vavra and Holechek (1980), Johnson (1982), and Wydeven and Dahlgren (1982). However, based on prairie dog stomachfecal comparisons made by Wydeven Dahlgren (1982) and Summers and Linder (1978), fecal material of black-tailed prairie dogs provided reliable diet estimates of grasses and forbs throughout our study.

The results of this study indicate that high densities of prairie dogs in western South Dakota may be an important negative influence on some native perennial grasses. Grasses eaten most commonly (sand dropseed, needleleaf sedge, wheatgrasses and blue grama) and highly preferred grasses (ring muhly, green needlegrass and sand dropseed)are undoubtedly reduced through the graminivorous feeding habits of these rodents. Long-term grazing of perennial grasses in combination with low forb consumption by prairie dogs will ultimately result in a change in plant species composition. Several years of prairie dog use might occur before pronounced shifts in species composition would be noticed.

\section{Literature Cited}

Baumgartner, L.L., and A.C. Martin. 1939. Plant histology as an aid in squirrel food habitat studies. J. Wildl. Manage. 3:266-268.

Bonham, C.D., and A. Lerwick. 1976. Vegetation changes induced by prairie dogs on shortgrass range. J. Range Manage. 29:221-225.

Collins, A.R., J.P. Workman, and D.W. Uresk. 1984. An economic analysis of black-tailed prairie dog (Cynomys ludoviianus) control. J. Range Manage. 35:358-361.

Curtis, J.T., and R.P. McIntosh. 1959. The inter-relations of certain analytic and synthetic phytosociological characters. Ecology 31:434-455.
Daubenmire, R. 1959. A canopy-coverage method of vegetation analysis. Northwest Sci. 33:43-64.

Fagerstone, K.A., H.P. Tietjen, and G.K. LaVoic. 1977. Effects of range treatment with 2,4-D on prairie dog diet. J. Range Manage. 30:57-60.

Fagerstone, K.A., H.P. Tietjen, and O. Williams. 1981. Seasonal variation in the diet of black-tailed prairie dogs. J. Mammal. 62:820-824.

Hansen, R.M., and I.K. Gold. 1977. Black-tailed prairie dogs, desert cottontails and cattle trophic relations on shortgrass range. J. Range Manage. 30:210-213.

Holechek, J.L., M. Vavra, and R.D. Pieper. 1982. Determination of range herbivore diets: A review. J. Range Manage. 35:309-315.

Johnson, M.K. 1982. Frequency sampling for microscopic analysis of botanical compositions. J. Range Manage. 35:541-542.

Johnson, M.K., H. Wofford, H.A. Pearson. 1983. Digestion and fragmentation: Influence on herbivore diet analysis. J. Wildl. Manage. 47:877-879.

Kelso, H. 1939. Food habits of prairie dogs. U.S. Dep. Agr. Circ. 529.

Krueger, W.C. 1972. Evaluating animal forage preference. J. Range Manage. $35: 471-475$.

Merriam, C. 1902. The prairie dog of the Great Plains. p. 257-270. In: Yearbook of the United States Department of Agriculture, Wash Gov. Print. Off.

Oosting, H.J. 1956. The study of plant communities. W.H. Freeman and Co., San Francisco, California.

Rogers, L.E., and D.W. Uresk. 1974. Food plant selection by the migratory grasshopper (Melanoplus sanguinipes) within a cheatgrass community. Northwest Sci. 48:230-234.

Siegel, S. 1956. Non-parametric statistics for the behavioral sciences. McGraw-Hill Book Co., New York.

Sparks, D.R., and J.C. Malechek. 1968. Estimating percentage dry weights in diets using a microscope technique. J. Range Manage. 21:264-265.

Summers, A., and R.L. Linder. 1978. Food habits of the black-tailed prairie dog in western South Dakota. J. Range Manage. 31:134-136.

Tileston, J.V., and R.R. Lecheitner. 1966. Some comparisons of the blacktailed and white-tailed prairie dogs in North-Central Colorado. Amer. Midland Nat. 75:292-316.

Uresk, D.W., and W.H. Rickard. 1976a. Diets of steers on a shrub-steppe rangeland in south-central Washington. J. Range Manage. 29:464-466.

Uresk, D.W., and W.H. Rickard. 1976b. Livestock forage and mineral relations on a shrub-steppe rangeland in northwestern United States of America. p. 25-31. In: Nuclear Techniques in Animal Production and Health Proceedings, Feb. 2-6, Vienna, Austria. International Atomic Energy Agency.

Uresk, D.W., and A.J. Bjugstad. 1983. Prairie dogs as ecosystem regulators on the Northern High Plains. p. 91-94. In: C.L. Kucera, (ed.). Proceedings of Seventh North American Prairie Conference, Aug. 4-6, 1980 Southwest Missouri State Univ., Springfield.

Vavra, M., and J.L. Holechek. 1980. Factors influencing micro-histological analysis of herbivore diets. J. Range Manage. 33:371-374.

Wydeven, P.R., and R.B. Dahlgren. 1982. A comparison of prairie dog stomach contents and feces using a microhistological technique. J. Wildl. Manage. 46:1104-1108.

MOVING? Please try to give us four weeks notice. Send your present address label and this form to Society for Range Management

2760 W. 5 th Ave.

Denver, Colo. 80204

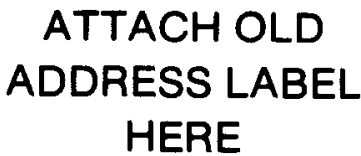

Name $\ldots \ldots \ldots \ldots \ldots \ldots \ldots \ldots \ldots \ldots \ldots$
New Address $\ldots \ldots \ldots \ldots \ldots \ldots \ldots \ldots \ldots$
Clty $\ldots \ldots \ldots \ldots \ldots \ldots \ldots \ldots \ldots \ldots \ldots$ 